\title{
Information Technology Investments And Aggregate Productivity
}

Paul Moon Sub Choi, Ewha Womans University, Republic of Korea

Hakyoul Choe, Korea Advanced Institute of Science and Technology, Republic of Korea

\begin{abstract}
Earlier studies have shown positive and large impacts of information technology (IT) investments on aggregate products in the nascent stage. However, this causal inference may not be applicable in the adult regime with a diminishing marginal productivity. We conduct a 52 cross-country analysis on a 15 year data of IT capital stocks, rather than flows as used in the literature. Controlling for country and time effects, the empirical implications of our study are as follows: First, the IT investment intensity positively affects aggregate productivity controlling for labor, assets, and financial markets. Second, the relative contribution has decreased as the law of diminishing returns predicts. Lastly, software and services have gained more capital allocation on relative terms in exchange for less on hardware. This finding contrasts with the existing argument that the hardware-software mix is time-constant due to substitution.
\end{abstract}

Keywords: Management Information System; Information Technology Investments; Aggregate Productivity

\section{INTRODUCTION}

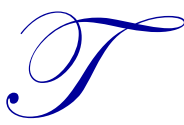

he inconclusive association between information technology (IT) investments and productivity has attracted much debate in the last two decades. According to a World Bank (2009), IT investments account for 7.5 percent of the annual gross domestic products (GDP) and 40 percent of the total capital expenditure of the U.S. Yet, direct and visible impacts of IT investments on productivity have persistently been questioned. According to an Slye et al (2010) report, the U.S. federal government allocated $\$ 86$ billion to IT purchases and services in the fiscal year of 2010 and possible deadweight losses of unproductive investments do moot a serious performance evaluation.

Loveman (1988) conducted an econometric analysis, for the first time in the literature, on a sample of 60 firms and argues that the IT investments yield insignificant productivity increases. On the contrary, Brynjolfsson (1993) and Brynjolfsson and Hitt (2003) show there are positive causalities based on their firm-level empirical studies. Their findings are also supported by Lee and Barua (1999) who use the same MPIT database as Loveman (1988) used. Autor et al. (2003) describe how introduction of computers reduced manual and routine tasks while increased demand for non-stylized expertise. This work-site pattern has been also documented in the U.K. and former West Germany, further confirming the effects of computers on the level of labor skills and demand for labor.

Two separate groups of studies have been developed in the literature: (1) What process the IT investments undergo while enhancing productivity; and (2) cross-industry and cross-country comparisons of the productivity impacts of IT investments. According to the 2009 annual report of Ministry of Internal Affairs and Communications of Japan, the productivity gap between the U.S. and Japan is explained by the cross-border difference in IT capital stocks. Also, in the cross-section of developed countries, the productivity increase is higher the higher the IT capital stocks.

Earlier studies have shown positive and large impacts of information technology (IT) investments on aggregate products in the nascent stage. However, this causal inference may not be applicable in the adult regime with a diminishing marginal productivity. We conduct a fifty two cross-country analysis on a fifteen year (1995-2009) data of IT capital stocks and real variables rather than flows and nominal, respectively, as used in the literature. Controlling for country and time effects, the empirical implications of our study are as follows: First, the IT investment intensity positively affects aggregate productivity controlling for labor, assets, and financial markets. 
Second, the relative contribution has decreased as the law of diminishing returns predicts. Lastly, software and services have gained more capital allocation on relative terms in exchange for less on hardware. This finding contrasts with the existing argument that the hardware-software mix is time-constant due to substitution.

The remainder of this paper is as follows: We compare an array of research analytics and empirics in the existing literature in Section 2. Section 3 proposes our model. We describe our data and conduct econometric analyses in Sections 4 and 5, respectively. Section 6 concludes.

\section{LITERATURE REVIEW}

\subsection{Managerial Information Systems and Aggregate Productivity}

Econometric methodologies are widely used in various areas within managerial information systems: Behavioral analysis, and country, industry and firm-level effects of IT. The IT productivity paradox in literature during the 1990's procreated a slew of research agenda on productivity effects of IT investments. The most stylized objective function during then augments an IT investment variable to the conventional Cobb-Douglas bivariate production function with labor and capital inputs (Cobb and Douglas, 1928). Regressions are conducted on a log-transformation of the trivariate production function:

$$
Y=A L^{\alpha} K^{\beta}(I T)^{\gamma}
$$

Park et al. (2007) show that the productivity of an IT developing country improves as the cumulative IT knowhow embedded in the imports from IT developed exporters is absorbed. Kudyba and Diwan (2002), based on their 500 firm-level database, conclude that IT investments increasingly enhances firm-level productivity over time. Mittal and Nault (2009) analyzed 19 industries and find that (1) IT investments yield positive externalities on labor and capital productivities in non-IT divisions within the sample companies; and (2) those marginal productivities vary in the cross-section of industry-level IT-intensity (Table 1).

Table 1

Recent references on productivity effects of IT investments.

\begin{tabular}{|c|c|c|c|}
\hline & Park et al. (2007) & Kudyba and Diwan (2002) & Mittal and Nault (2009) \\
\hline $\begin{array}{l}\text { Research } \\
\text { question }\end{array}$ & $\begin{array}{l}\text { Do IT investments improve } \\
\text { productivity? }\end{array}$ & Do IT investments improve productivity? & $\begin{array}{l}\text { Do IT investments indirectly affect } \\
\text { productivity? }\end{array}$ \\
\hline \multirow[t]{2}{*}{ Analysis level } & Country level & Firm level & Industry level \\
\hline & (IT-developed vs. developing) & Partly, industry level & (High IT-intensive industry indicated) \\
\hline Method & Unit root test & OLS, Chow test & $\begin{array}{l}\text { GLS, Autocorrelation (AR(1), } \\
\text { heteroskedastcity }\end{array}$ \\
\hline \multirow[t]{4}{*}{ Model } & Cobb-Douglas function & Cobb-Douglas function & Cobb-Douglas function \\
\hline & $\begin{array}{l}\quad=A{ }^{N} K \quad L^{1} \\
\text { Log-transformation of TFP: }\end{array}$ & $\ln Q_{i j}=1 \ln I L_{i j}+2 \ln L i_{j}+3 \ln I K_{i j}+4 \ln K_{i j}$ & $\begin{array}{c}=A K \quad L \quad Z \\
\text { Log-transformation: }\end{array}$ \\
\hline & TFP $\overline{K L^{1}}$ & & $y=a+a k+l+z+$ \\
\hline & $\log T F P={ }_{0}+F\left(S^{d}, S^{f}, z\right)$ & & \\
\hline \multirow[t]{2}{*}{ Data } & 39 countries ( 4 groups) & 500 firms & 912firm-years $(19$ firms $\times 48$ years $)$ \\
\hline & Period: $1992-2000$ & Period: $1994-1997$ & $\begin{array}{l}19 \text { SIC codes (industries) } \\
\text { Period: } 1953-2000\end{array}$ \\
\hline \multirow{5}{*}{$\begin{array}{l}\text { Independent } \\
\text { var. }\end{array}$} & $\mathrm{S}^{\mathrm{d}}:$ Domestic IT investments & L: labor & A: factor neutral technological change \\
\hline & $\mathrm{S}_{\mathrm{f}}^{\mathrm{f}}$ Foreign (exporters ) IT investments & K: capital & (embedded indirect effects of IT) \\
\hline & Z: Controls (PC's, networks etc.) & IL: IT labor & $\mathrm{K}$ : quantity of non-IT capibal \\
\hline & & IK: IT capital & L: quantity of labor \\
\hline & & & Z: quantity of IT capital \\
\hline \multirow{3}{*}{$\begin{array}{l}\text { Dependent } \\
\text { var. } \\
\text { Findings }\end{array}$} & TFP (Total factor productivity) & $\begin{array}{l}\text { Q: Sales revenue } \\
\text { Q: value added }\end{array}$ & $\gamma:$ quantity of physical output \\
\hline & TFP (Total factor productivity) & IT capital proves productivity $\frac{d Q}{d I K}>0$ ) & $\begin{array}{l}\text { Difference between IT-intensive vs. } \\
\text { non-IT-intensive industries. }\end{array}$ \\
\hline & Cointegration test & Contribution IT capital to productivity $(\beta)$ increases over time & $\begin{array}{l}\text { Benefits from IT investments are } \\
\text { indirect rather than direct. }\end{array}$ \\
\hline
\end{tabular}




\subsection{Structure of Managerial Information Systems}

Another strand of literature is on analyzing the long-run trends of IT investments. It has been generally accepted that the hardware-software mix is initially heavier on hardware in IT investments while the software proportion bulges with an "S"-curve. The reasoning is as follows: (1) The price of an iso-functional hardware decreases over time, according to Moore's law (Larus 2009); while (2) hardware and software are assumed to be perfect substitutes like the labor and capital inputs in a typical production function; and (3) highly non-stylized tasks increasingly require software expenditure.

However, Gurbaxani and Mendelson (1992) conducted regressions and show that the hardware-software mix is statistically constant. They determine the value of an information service product $(W)$ with respect to the quantities of hardware $(s)$ and software $(h)$ as follows:

$$
W\left(s_{t}, h_{t}\right)=A s_{t}^{\alpha} h_{t}^{\beta} .
$$

They defined the hardware-software budget ratio as

$$
\operatorname{LRATIO}_{t} \equiv \log \left(H_{t} / S_{t}\right)
$$

then regressed the ratio onto the gross domestic products (GDP) to find that the ratio remained statistically timeinvariant. Specifically, (1) hardware investments outpaced those of software during economic booms; and (2) reversed during busts.

\subsection{Econometric Analyses of IT Events and Investment Outcomes}

Econometric analytics have been pervasively adopted in quantitative research of managerial information systems and, yet, the usage has been paid more caution and prudence. For example, ordinary (OLS) and/or generalized least squares (GLS) methods had been applied without autocorrelation tests on time series datasets. Acknowledging such procedural misconduct, Park et al. (2007) and Mittal and Nault (2009) conducted autocorrelation and cointegration tests before confirming model fitness. Also, Chow's (1960) test has been used to verify statistically significant regime-shifts as the IT industry experienced major innovations: Incoming of PC-era (mid-1980's), introduction of Windows OS (early 1990's), mass-distribution of DBMS (1990's), infiltration of the Internet (late 1990's), and expansion of the high-speed Internet (early 2000's).Econometric analytics of structural breaks are also employed in evaluating productivity impacts upon IT capital accumulation (Kudyba and Diwa, 2002). 
Table 2

Major references, sample periods, and data sources.

\begin{tabular}{|c|c|c|}
\hline Reference & Sample description & Sources \\
\hline \multirow[t]{4}{*}{ Brynjolfsson and Hitt (2002) } & $1987-1994$ & CII: capital stock of computers \\
\hline & Balanced panel, 527 large US firms & Compustat II: public financial information \\
\hline & & BLS: computer rental prices for the capital factors \\
\hline & & IDG: computer HW and related expenses \\
\hline \multirow[t]{3}{*}{ Hitt et al. (2002) } & $1986-1998$ & SAP: ERP adoption using license agreement \\
\hline & 5603 firms & Compustat II: productivity, market value, firm performance \\
\hline & & CII: information technology use, firm level IT stocks, HW, capacity of \\
\hline \multirow[t]{2}{*}{ Hitt and Brynjolfsson (1996) } & $1988-1992$ & IDG: IT spending by large firms \\
\hline & Panel, 370 largest firms & Compustat II: output, capital, labor, etc. \\
\hline \multirow[t]{4}{*}{ Kudyba and Diwan (2002) } & $1994-1997$ & Information Week: \\
\hline & & CII: IS budget, IT employees, revenue, etc. \\
\hline & & SEC: corporate disclosure reports, non-IT capital, costs of goods sold, \\
\hline & & Computer World: IT salary \\
\hline \multirow[t]{4}{*}{ Park et al. (2007) } & $1992-2000$ & OECD: capital shares, GDP, physical capital stock, labor \\
\hline & 39 countries & PWT 6.1: real GDP \\
\hline & & Worldbank: shares of ICT expenditures in GDP \\
\hline & & NBER-United Nations Trade: ISIC bilateral import flow data \\
\hline \multirow[t]{2}{*}{ Mittal and Nault (2009) } & 31 years & BLU: MFP data set of two-digit SIC, industry output, cost of energy, \\
\hline & Manufacturing sector & materials, and service purchased, price deflators, IT capital stocks, \\
\hline Gurbaxani and Mendelson (1992) & 1976-1984 yearly data & IDC: IS spending in US (Computer Industry Report), IS budget \\
\hline Mendelson (1987) & 98 systems from 17 vendors & Computerworld: average cost per MIPS \\
\hline \multirow[t]{2}{*}{ Anderson (2003) } & $1999-2002$ & SEC: stock prices, Y2K spending, R\&D spending, earnings. \\
\hline & Fortune 1000 firms & \\
\hline
\end{tabular}

\subsection{Analytics}

\section{MODELS}

\subsubsection{Investments in Managerial Information System and Productivity}

A Cobb-Douglas production function is conveniently assumed to gauge the productivity effect of an IT investment: An IT variable is augmented to the conventional labor and capital inputs. A log-transformation is used for linear regressions:

$$
\log Y_{t}=\mathrm{c}+\alpha \log L_{t}+\beta \log K_{t}+\gamma \log I T_{t}+\varepsilon_{t}
$$

where $\gamma$ measures the percentage increase in productivity per every percentage additional IT capital expenditure. An IT investment may affect productivity directly; indirectly by labor and or capital productivity improvements via agents' learning experiences. As these propagations are time-varying, each variable is time-indexed. The ITintensity has implications for the extent of IT growth: The marginal productivity of a later period may be weakened compared to that of an earlier stage due to the law of diminishing marginal return. The vintage classification of IT investments has to be considered accordingly.

\subsubsection{Structure of Investments in Managerial Information Systems}

The IT capital expenditures are on hardware, software, and services. In the literature, services branched out of software as corporate demand for services auxiliary to IT software diversified and complicated: Entrepreneurial resource planning (ERP), data warehouse, data mining, consumer relations management (CRM), supply chain management (SCM) etc. In addition, un-interrupted and un-resting utilization and maintenance features of software are unlike those of services. 
The dynamics of IT investments are determined by intertemporal and income factors: First, the natural increase of IT capital expenditure over time is due to the additional purchases of services and software to utilize, operate, and maintain the existing hardware assets. Also, short replacement periods of IT equipment and software prescribe timely retire of outdated IT purchases in exchange for newer ones. Second, firm and sovereign-level demand for capital goods increase when upon increments in sales revenue and GDP, respectively, and so do IT investments. In the following subsection, we embed hardware, software and services in the econometric model to examine their time and income-dependent effects on productivity.

\subsection{Panel Data Econometrics}

Our IT productivity data bears the desirable features of a typical panel dataset: Idiosyncratic heterogeneity, variability, and stationary measurement of changes (Baltagi, 2008).

\subsubsection{Idiosyncratic Heterogeneity}

IT investments vary country to country. Since IT capital goods are an infrastructure auxiliary to production, there are a number of concurrent factors that have to be aware of: Short or mid-run time-invariant Illiteracy, education level etc. In addition, politico-economic regime and structure, degree of market regulation, governance, colonial historical background, communication and network infrastructure, cultural aspects can affect infiltration and utilization of information systems that expand societal openness and mutual exchange. For example, a market-oriented country with a stringent transparency expectation will be relatively quick in adopting large scale information systems, and the ex post efficiency of capitalizing the investments will be relatively high thereby significantly improving the aggregate productivity. Also, a former colony or highly foreign-dependent country is highly likely to adopt the IT infrastructure from its previous political colonizer or dominant trading counterpart on contagion.

Deaton (1995) claims when statistically testing a hypothesis that a small farm is more productive than a lager lot, unobserved heterogeneity such as land quality has to be controlled for. Likewise, the timing and effect of IT investments can depend on the existing country-level conditions.

For example, Hong Kong, Singapore, and Korea took relatively short periods to reach high infiltration of internet and mobile telecommunication infiltration due to their relative narrow land masses and high population densities. On the contrary, this is unlikely the case in the U.S. and Canada where the clientele is geographically dispersed and, thus, the set-up costs and time to break-even can be high. According to an OECD (2008) report, 14\% of South Korean population and an average OECD member had access to the high speed Internet by 2001 whereas an average OECD member country achieved it by 2006 .

\subsubsection{More Informative Data, More Variability}

A cross-sectional data typically has a high variability. Data variability stems from variations due to group sizes, group characteristics, and inter-group interactions, where the size effect is the largest (Baltagi, 2008). In an IT investment effect analysis, GDPs, populations and capital sizes can contribute to data variability. For example, an IT capital investment equivalent to a change that amounts to $1 \%$ of labor force in Mainland China can result in a higher productivity change than that of the whole population in Hong Kong.

\subsubsection{Identity and Measure Effects in Pure Cross-Section or Pure Time-Series Data}

A stationary panel data may suffer an information loss in the cross-section. A panel of cross-sectional data "strings" can provide an array of factors that affect a time series of interest. For example, in order to explain the annual unemployment ratio of $10 \%$ that remained intact on a year-on-year basis one must designate the key explanatory and control variables for every cross-section of contemporaneous observations or estimates. Likewise, two separate observations of IT hardware investments in 1995 and 2000 that appear to be of the same numerical values are not statistically different unless other variables have been accounted for. Panel data analysis can overcome this impasse. 
Known limitations of panel data analysis are the errors associated with model designing, data collection, and estimation. Research coverage, non-response, interview period, and recall failure may lead to data collection errors, while imprecise questionnaire, erroneous record, purposefully distorted responses to estimation errors. This research sources on macroeconomic data from literature-proven, systematic, and consistently maintained databases from IDC, World Bank, PWT etc., and we believe our panel econometric analytics are less prone to the aforementioned errors.

\section{THEORY AND HYPOTHESES}

\subsection{Investments in Information Systems and Aggregate Productivity}

Likewise, in labor and capital, an increase in IT investments brings a positive GDP growth. An IT utilization can forward some of the labor inputs from the existing manual and repetitive tasks to another higher value-added business lines. In South Korea, a daily average 100 issuances of export and import-related government permits are requested and granted on an electronic basis. This reportedly resulted in reduced in-person visits, paper documents, manual errors which collectively saved 6 trillion won-worth costs in 2009 according to Institute for International Trade (Choi 2010) in South Korea. An increase in IT investments can shore up aggregate revenues by efficiently reallocating labor and capital into more productive usages.

H1: There is a positive association between an IT investment and aggregate productivity.

Countries vary in terms of the existing IT infrastructure, for example the infiltration ratios of high speed internet, PCs, wireless communication devices etc. An identical amount of IT investments will therefore yield differing productivity improvements in the cross-section of countries. Purchases of the same 100 units of PCs in both U.S. and Indian branches will imply significantly different productivity effects.

H2: Aggregate productivity effects of aggregate investments in information systems are not identical in the crosssection of countries.

When analyzing the productivity consequences of IT investments, one must consider both diminishing returns and network effects. An IT investment effect materializes upon building complementary assets, rather than directly, and when the number of users exceeds a certain threshold. The Internet which began as Advanced Research Projects Agency Network (ARPANET) in 1969 took 30 years to be widely adopted by the mass, and wireless communication with a phenomenal leap in the number of subscribers upon light-weighing and affordable mobile devices became available after mid-1990's.

These incremental momentums of productivity past thresholds of users or assets of IT investments can be considered as learning and network effects. An IT installation is a capital good that depreciates and whose returns diminish over time. During the 15 year sample period (1995-2009), we may observe both network and diminishing market product effects. Thus, we need control for the IT investment vintage of sample countries: Saturated IT installations in developed economies versus nascent IT investments in emerging or developing sovereignties.

H3: The productivity effects of IT system investments diminish over time.

\subsection{Structure of Investments In Information Systems}

Gurbaxani and Mendelson (1992) report that even as IT-driven services sophisticate and specialize hardwaresoftware budget allocation ratio should remain constant due to substitution of the existing hardware to cost-saving and up-performing replacements, unlike the conventional wisdom in the literature that supporting software expenditures increase. We test their finding, which is based on data from 1980's, by using a 15 year (1995-2009) and 52 cross-country database.

H4a: Investment coefficients of hardware and software will remain intact even as aggregate products increase. 
Maintenance and replacement costs of both hardware and software increase over time, and so do IT investments. Development and operation costs of software can be assumed to grow like an "S"-curve as the information system investments gain. The marginal cost of software diminishes as IT investments mature as technological innovations and steeping competition gravitate prices. When the investment cycle fully peaks there are replacement orders on information system goods and services. Unlike the software that faces wage hikes and employment rigidity, the hardware will continue save costs over time: The latter substitutes the former in terms of budget allocation.

H4b: As aggregate products increase, investments on hardware gain more than on software.

H4c: Investment coefficients of hardware and software will remain over time.

IT services include installation, customization, and maintenance of hardware equipment and software programs. Accordingly, demand for IT services move in tandem with those for IT investments in hardware and software. There is an upward climb in IT service expenditures over time as new and replacement investments in hardware and software accumulate.

H5a: There is a positive association between IT service investments and IT expenditures in hardware and software.

H5b: IT service investments rise over aggregate products.

H5c: IT service investments rise over time.

\section{DATA}

\subsection{Databases}

Analyzing country-level factor productivity effects requires time series data of GDP, labor, capital and IT investments. We sourced them from a variety of databases from World Bank, International Monetary Fund (IMF), Organization for Economic Co-operation and Development (OECD), and Penn World Trade (PWT). The OECD database only compiles those of member countries'. The World Bank database compiles nominal GDPs. The PWT database (Version 6.3, August 2009) keeps the records of all sovereign economies from 1950 until 2007 and reports real GDP estimates. We further extrapolated year 2008 real GDP estimates by extracting real GDP growth rates from GDP growth rates and deflators from the World Bank database. Factor composition ratios are estimated from total labor forces, employment ratios, and capital-GDP ratios available from the World Bank. Country-level IT investment-related variables since 2003 are also available from the World Bank. The IDC database is a compilation of firm-level survey responses and research findings pertaining to managerial information system investments in 52 countries with a sample period of 1995 through 2009. The database has three investment categories: Hardware, software, and services. We converted the nominal estimates from the IDC database to real variables by using the GDP deflators available from the World Bank.

\subsection{Data Conversion and Missing Data Treatment}

A variety of data sources imply unstandardized data frequencies, formats etc. We thus compiled the collected data per "stack-by-cross-section" to be readily analyzable on a statistical program. Accordingly, we constructed a balanced data by eliminating the United Arab Emirates (U.A.E.), whose data is available since 2001, from the 53 country-IDC database. As a result, we arrived at a 52 cross-country database over 15 years as the finalized sample.

\subsection{Conversion from Capital Flows to Capital Stocks}

A majority of research in this area used IT capital flows, not stocks, due to difficulties in identifying and acquiring cumulative capital data sources and estimating the initial capital investments (Lee and Baura, 1997). In this study, we estimate the cumulative capital $\left(K_{i t}\right)$ in country $i$ by year $t$ as follows:

$$
K_{i t}=I N V_{i t}+\left(1-r_{t}\right) \cdot K_{i, t-1},
$$


where the existing value of capital $\left(K_{i, t-1}\right)$ is depreciated at $r_{t}$ and re-enforced by the fresh capital expenditure $\left(I N V_{i t}\right)$. We assumed a 5\% depreciation rate following Park et al. (2007).

In order to estimate the initial capital stocks in 1995, the first year in our sample period, we used the real GDP estimates from the PWT database and investments-GDP ratio from the World Bank database to arrive at the real investment amounts 1981 through 1995 . We applied a 5\% annual depreciation rate for the country-level capital stocks whereas $20 \%$ for the IT capital stocks due to the accelerated dilapidation nature of IT hardware equipment and software programs (Park et al., 2007). Since data compilation of IT capital stocks was neither consistent nor sufficient, we assumed the initial country-level capital stocks as four times the IT investments made in 1995.

Table 3

Description and sources of key variables.

\begin{tabular}{|c|c|c|c|c|}
\hline Variable & Unit & Description & Definition & Remark \\
\hline Gdp & $\times \$ 10^{3}$ & Gross domestic products & PWT 8.0 & \\
\hline Inv & $\times \$ 10^{3}$ & Aggregate investments & Annual total capital investments & GDP $\times$ capital ratio \\
\hline Sum & $\times \$ 10^{6}$ & Aggregate IT investments in flow & Sum of all IT investment sub-categories & IDC \\
\hline Hw & $\times \$ 10^{6}$ & Hardware investmetns & Computing and network equipment & IDC \\
\hline Sw & $\times \$ 10^{6}$ & Software purchases & Software packages, customization etc. & IDC \\
\hline Svc & $\times \$ 10^{6}$ & Services charges & Maintenance, operation, development etc. & IDC \\
\hline $\mathrm{K}$ & $\times \$ 10^{3}$ & Cumulative capital & PWT 8.0 & \\
\hline $\mathrm{K} 2$ & $\times \$ 10^{3}$ & Non-IT cumulative capital & & $\mathrm{K}_{\mathrm{t}}-\mathrm{ITS}_{\mathrm{t}}$ \\
\hline Its & $\times \$ 10^{6}$ & Aggregate IT capital & & \\
\hline $\mathrm{Lab}$ & 1,000 's & Labor & PWT 8.0 & \\
\hline Grp & Binary & 1 for IT-developed country, 0 o.w. & 1 for over $6 \%$ of IT investments-GDP ratio & \\
\hline Time & Categorical & Year categorical variable & $1995-2009$ & \\
\hline
\end{tabular}

Table 4

Representative statistics of key variables.

\begin{tabular}{|c|c|c|c|c|c|c|}
\hline Variable & Description & Mean & Median & Maximum & Minimum & Std. Dev. \\
\hline$\overline{\text { Gdp }}$ & Gross dosmestic products $\left(\times 10^{6}\right)$ & 927,489 & 287,809 & $13,149,344$ & 33,378 & $1,823,060$ \\
\hline Inv & Aggregate investments $\left(\times 10^{6}\right)$ & 224,871 & 68,426 & $4,521,596$ & 2,959 & 473,551 \\
\hline Sum & Aggregate IT investments in flow & 20,969 & 4,587 & 511,793 & 21 & 59,282 \\
\hline $\mathrm{Hw}$ & Hardware investments & 9,225 & 2,441 & 192,291 & 16 & 23,471 \\
\hline Sw & Software purchases & 3,846 & 614 & 134,872 & 3 & 13,559 \\
\hline Svc & Service charges & 7,898 & 1,274 & 211,346 & 2 & 23,326 \\
\hline K & Cumulative capital $\left(\times 10^{6}\right)$ & $2,932,010$ & 886,178 & $40,347,576$ & 107,889 & $5,796,048$ \\
\hline K2 & Non-IT cumulative capital $\left(\times 10^{6}\right)$ & $2,846,253$ & 857,112 & $38,350,057$ & 106,876 & $5,577,348$ \\
\hline Its & Aggregate IT capital & 85,793 & 16,977 & $2,149,170$ & 279 & 246,736 \\
\hline Lab & Labor inputs $\left(\times 10^{6}\right)$ & 41.0 & 9.6 & 777.4 & 0.9 & 114.2 \\
\hline StockReturn & Return of the representative stock market return (\%) & -0.28 & -0.85 & 494.00 & -2.00 & 15.66 \\
\hline StockMarket & Ratio of the stock market capitalization over GDP (\%) & 65.92 & 46.71 & 606.00 & 0.02 & 66.91 \\
\hline
\end{tabular}

\subsection{Group and Time Dummies}

In order to control for the growing versus mature status in terms of IT investments, we define the threshold as 5\% annual IT investments out of the GDP: The IT-mature countries are assigned with ones as a dummy indicator. The trend effect is considered by applying year dummies 1996 through 2008.

\section{RESULTS}

\subsection{Productivity Effects of IT Investments}

We identified 4 models that explain the productivity effects of IT investments: Capital expenditure (LogInv) and concurrent yearly IT investments in flow (LogSum) affect GDPs (LogGdp) in Model 1. IT investments in stock 
(LogIts) are used in Model 2 instead of flow (LogSum) as in Model 1 to seek a possibly different inference. We distinguish the non-IT capital stock (LogK2) from the IT capital stock (LogIts) in Model 3. Lastly, we estimate the coefficients of factors with autoregression in Model 4.

$$
\begin{aligned}
& \log G d p_{t}=\text { Intercept }+\alpha{\log L a b_{t}}_{t} \beta \operatorname{LogInv}_{t}+\gamma \operatorname{LogSum}_{t}+\varepsilon_{t} . \\
& \log G d p_{t}=\text { Intercept }+\alpha \log L a b_{t}+\beta \log K_{t}+\gamma \operatorname{LogIts}_{t}+\varepsilon_{t} . \\
& \log G d p_{t}=\text { Intercept }+\alpha \log \operatorname{Lab}_{t}+\beta \operatorname{LogK} 2_{t}+\gamma \operatorname{LogIts}_{t}+\varepsilon_{t} . \\
& D \log G d p_{t}=\text { Intercept }+\alpha D \log L a b_{t}+\beta D \log K 2_{t}+\gamma D \operatorname{LogIts}_{t}+\varepsilon_{t} .
\end{aligned}
$$

Table 5

Productivity effects of IT investments.

\begin{tabular}{|c|c|c|c|c|}
\hline & Model 1 & Model 2 & Model 3 & Model 4 \\
\hline \multirow[t]{2}{*}{ Intercept } & $4.378 * * *$ & $2.956 * * *$ & $3.079 * * *$ & 0.003 \\
\hline & 32.582 & 15.889 & 16.702 & 0.368 \\
\hline \multirow[t]{2}{*}{$\log L a b$} & $0.236 * * *$ & $0.245 * * *$ & $0.249 * * *$ & \\
\hline & 20.757 & 19.356 & 19.642 & \\
\hline \multirow[t]{2}{*}{ DLogLab } & & & & $0.388 * * *$ \\
\hline & & & & 4.678 \\
\hline \multirow[t]{2}{*}{ LogInv } & $0.588 * * *$ & & & \\
\hline & 29.410 & & & \\
\hline \multirow[t]{2}{*}{$\log K$} & & $0.565 * * *$ & & \\
\hline & & 26.546 & & \\
\hline \multirow[t]{2}{*}{$\operatorname{LogK} 2$} & & & $0.546 * * *$ & \\
\hline & & & 26.144 & \\
\hline \multirow[t]{2}{*}{ DLogK2 } & & & & $0.369 * * *$ \\
\hline & & & & 4.748 \\
\hline \multirow[t]{2}{*}{ LogSum } & $0.142 * * *$ & & & \\
\hline & 13.705 & & & \\
\hline \multirow[t]{2}{*}{ LogIts } & & $0.145 * * *$ & $0.159 * * *$ & \\
\hline & & 13.582 & 15.411 & \\
\hline \multirow[t]{2}{*}{ DLogIts } & & & & $0.092 * * *$ \\
\hline & & & & 3.544 \\
\hline No. of Obs. & 780 & 780 & 780 & 780 \\
\hline $\mathrm{R}^{2}$ & 0.971 & 0.967 & 0.967 & 0.111 \\
\hline
\end{tabular}

For the pooled OLS regression results herein, the dependent variables are LogGdp for Models 1, 2, and 3, and DLogGdp for Model 4. The numerical values below coefficient estimtes are their t-statistics. ***,**, and * stand for statistical significance based on two-sided tests at the $1 \%, 5 \%$, and $10 \%$ level, respectively.

In Table 5, all coefficient estimates are shown to be statistically and economically significant. In Models 1, 2, and 3, the coefficient estimates of labor factor (LogLab) are in the range of 0.236 and 0.249: A 1 percent increase in labor input gives rise to a GDP growth of roughly 20 basis points. The productivity effect of capital factor has a higher magnitude as the range of coefficient estimates are 0.369 and 0.588: A 1 percent increase in capital expenditure yields a GDP growth of up to circa 60 basis points. In Models 1 through 4, although all models show high fitness with $\mathrm{R}^{2}$ s in the range of $11.1 \%$ and $97.1 \%$, we choose Model 3 as our inference toolkit since it employs the capital input in stock while separating the non-IT portion from the IT capital stock. 
Table 6

Productivity effects of IT capital stocks.

The dependent variable is LogGdp. Fixed effects follow the feasesible geralized least squares (FGLS) method. The numerical values below coefficient estimtes are their t-statistics. ***, **, and * stand for statistical significance based on two-sided tests at the $1 \%, 5 \%$, and $10 \%$ level, respectively.

\begin{tabular}{|c|c|c|c|c|c|c|c|c|}
\hline & Model 1 & Model 2 & Model 3 & Model 4 & Model 5 & Model 6 & Model 7 & Model 8 \\
\hline \multirow[t]{2}{*}{ Intercept } & $4.765 * * *$ & $6.496 * * *$ & $4.542 * * *$ & $4.574 * * *$ & $4.568 * * *$ & $4.070 * * *$ & $4.088 * * *$ & $4.105 * * *$ \\
\hline & 14.686 & 14.946 & 13.044 & 13.099 & 13.097 & 11.282 & 11.370 & 11.378 \\
\hline \multirow[t]{2}{*}{ LogLab } & $0.196 * * *$ & 0.089 & $0.270 * * *$ & $0.263 * * *$ & $0.267 * * *$ & $0.271 * * *$ & $0.268 * * *$ & $0.269 * * *$ \\
\hline & 3.509 & 1.540 & 4.517 & 4.404 & 4.476 & 9.172 & 9.173 & 9.137 \\
\hline \multirow[t]{2}{*}{$\operatorname{LogK} 2$} & $0.474 * * *$ & $0.396 * * *$ & $0.519 * * *$ & $0.516 * * *$ & $0.517 * * *$ & $0.550 * * *$ & $0.547 * * *$ & $0.547 * * *$ \\
\hline & 14.153 & 11.180 & 14.407 & 14.283 & 14.328 & 16.503 & 16.443 & 16.405 \\
\hline \multirow[t]{2}{*}{ LogIts } & $0.104 * * *$ & $0.058 * *$ & $0.050 * * *$ & $0.053 * * *$ & $0.052 * * *$ & $0.053 * * *$ & $0.057 * * *$ & $0.055 * * *$ \\
\hline & 8.394 & 4.061 & 3.669 & 3.921 & 3.780 & 3.850 & 4.152 & 3.994 \\
\hline \multirow[t]{2}{*}{ StockReturn } & & & 0.000 & & 0.000 & 0.000 & & 0.000 \\
\hline & & & -1.623 & & -1.608 & -1.598 & & -1.581 \\
\hline \multirow[t]{2}{*}{ StockMarket } & & & & -25.427 & -24.976 & & -31.686 & -31.194 \\
\hline & & & & -1.202 & -1.182 & & -1.532 & -1.510 \\
\hline \multirow[t]{2}{*}{ Trend } & & $0.010 * * *$ & & & & -0.001 & -0.001 & -0.001 \\
\hline & & 5.828 & & & & -0.478 & -0.552 & -0.460 \\
\hline Fixed Effect & Yes & Yes & Yes & Yes & Yes & & & \\
\hline Random Effect & & & & & & Yes & Yes & Yes \\
\hline No. of Obs. & 780 & 780 & 630 & 630 & 630 & 630 & 630 & 630 \\
\hline $\mathrm{R}^{2}$ & 0.995 & 0.995 & 0.996 & 0.996 & 0.996 & 0.956 & 0.836 & 0.835 \\
\hline
\end{tabular}

Panel regression results are reported in Table 6. All model specifications, Models 1 through 5, show positive productivity effects of labor ( $\log L a b)$, capital $(\operatorname{LogK} 2)$ and IT investment (LogIts) factors. The fixed-effect model (Model 3) shows a lower IT investment intensity than the pooled regression model (Model 1) with coefficient estimates of 0.050 and 0.104 , respectively.

We augment the IT-developed countries group dummy (ItDev) and trend term (Time) into Model 3 to settle with the finalize model identification:

$$
\log G d p_{t}=\text { Intercept }+\alpha \log L a b_{t}+\beta \log K 2_{t}+\gamma \operatorname{LogIts}_{t}+\delta \operatorname{Time}+\varepsilon_{t} .
$$


Table 7

Fixed-effect panel regressions of productivity effects.

The dependent variable is LogGdp. Fixed effects follow the feasesible geralized least squares (FGLS) method. The numerical values below coefficient estimtes are their t-statistics. ***,**, and * stand for statistical significance based on two-sided tests at the $1 \%, 5 \%$, and $10 \%$ level, respectively. The regresssion model is as follows: $\operatorname{LogGdp} t=$ Intercept $+\alpha \log \operatorname{Lab} t+\beta \operatorname{LogK} 2 t+\gamma$ LogItst $+\delta$ Time $+\varepsilon t$.

\begin{tabular}{lc}
\hline Variable & Estimate \\
\hline Intercept & $6.496^{* * *}$ \\
& 14.946 \\
LogLab & 0.089 \\
& 1.540 \\
LogK2 & $0.396^{* * *}$ \\
LogIts & $11.180^{* * *}$ \\
& $0.058^{* * *}$ \\
Time & 4.061 \\
& $0.010^{* * *}$ \\
Durbin-Watson & 5.828 \\
No. of Obs. & 0.373 \\
$\mathrm{R}^{2}$ & 780 \\
\hline
\end{tabular}

In Table 7, we report fixed-effect panel regressions of the productivity effects of IT investments with year and country effects of categorical variables. The coefficient estimates of the year categorical variable (Time) show decreasing GDP growth rates over time due to the law of diminishing returns of labor, capital and IT investment factors alike. The regression results reported in Table 7 appears to be robust to autocorrelation as the Durbin and Watson's $(1950,1951)$ statistic is insignificant. Overall, the results shown in Tables 6 and 7 are in favor of hypotheses $H 1, H 2$, and $H 3$.

\subsection{Structure of IT Investments}

In order to identify factors that affect investments in IT hardware, software and services, Gurbaxani and Mendelson's (1992) model that identifies GDP as a causal factor turned out statistically insignificant in our undocumented empirical analysis using the data described in Section 5. Instead, we extend from our specification (Model 3, Table 5) presented in Subsection 6.1.

In Panel A of Table 8, we verify seek determinants of IT hardware investments with (Models 2,4) and without (Models 1,3) the trend term with pooled (Models 1 and 2), fixed (Model 3) and random effect (Model 4) model specifications. The GDP (LogGdp) is shown to be increasing budget allocations in IT hardware investments with statistically and economically meaningful coefficient estimates in the range of 0.977 and 1.688: A 1 percent growth in aggregate income can roughly upsize capital expenditures in IT hardware equipment by more than 1 percent. The time effect (Trend) appears to shown intuitively positive signs.

$$
\begin{aligned}
& \log H w_{t}=\text { Intercept }+ \text { Trend }+\alpha \log G d p_{t}+\varepsilon_{t} . \\
& \log H w_{t}=\text { Intercept }+\alpha \log G d p_{t}+\varepsilon_{t} . \\
& \log S w_{t}=\text { Intercept }+ \text { Trend }+\alpha \log G d p_{t}+\varepsilon_{t} .
\end{aligned}
$$




$$
\begin{aligned}
& \log S w_{t}=\text { Intercept }+\alpha \log G d p_{t}+\varepsilon_{t} . \\
& \log S v c_{t}=\text { Intercept }+ \text { Trend }+\alpha \log G d p_{t}+\varepsilon_{t} . \\
& \log S v c_{t}=\text { Intercept }+\alpha \log G d p_{t}+\varepsilon_{t} .
\end{aligned}
$$

Table 8

Structure of IT investments: Hardward, software, and services.

Fixed effects follow the feasesible geralized least squares (FGLS) method. The numerical values below coefficient estimtes are their t-statistics.

\begin{tabular}{|c|c|c|c|c|}
\hline & Model 1 & Model 2 & Model 3 & Model 4 \\
\hline \multirow[t]{2}{*}{ Intercept } & $-4.789 * * *$ & $-4.839 * * *$ & $-13.793 * * *$ & $-5.502 * * *$ \\
\hline & -16.761 & -17.180 & -14.518 & -6.501 \\
\hline \multirow[t]{2}{*}{ Trend } & & $0.030 * * *$ & & $0.028 * * *$ \\
\hline & & 4.944 & & 8.129 \\
\hline \multirow[t]{3}{*}{ LogGdp } & $0.989 * * *$ & $0.977 * * *$ & $1.688 * * *$ & $1.029 * * *$ \\
\hline & 44.810 & 44.618 & 22.898 & 15.498 \\
\hline & 0.000 & 0.000 & 0.000 & 0.000 \\
\hline Pooled Effect & Yes & Yes & & \\
\hline Fixed Effect & & & Yes & \\
\hline Random Effect & & & & Yes \\
\hline No. of Obs. & 780 & 780 & 780 & 780 \\
\hline $\mathrm{R}^{2}$ & 0.721 & 0.729 & 0.944 & 0.481 \\
\hline \multicolumn{5}{|c|}{ Panel B: Software. } \\
\hline & Model 1 & Model 2 & Model 3 & Model 4 \\
\hline \multirow[t]{2}{*}{ Intercept } & $-6.388 * * *$ & $-6.500 * * *$ & $-23.755 * * *$ & $-5.022 * * *$ \\
\hline & -13.709 & -14.343 & -25.035 & -4.587 \\
\hline \multirow[t]{2}{*}{ Trend } & & $0.067 * * *$ & & $0.070 * * *$ \\
\hline & & 6.821 & & 19.509 \\
\hline \multirow[t]{2}{*}{ LogGdp } & $1.005 * * *$ & $0.978 * * *$ & $2.353 * * *$ & $0.861 * * *$ \\
\hline & 27.928 & 27.766 & 31.962 & 10.075 \\
\hline Pooled Effect & Yes & Yes & & \\
\hline Fixed Effect & & & Yes & \\
\hline Random Effect & & & & Yes \\
\hline No. of Obs. & 780 & 780 & 780 & 780 \\
\hline $\mathrm{R}^{2}$ & 0.501 & 0.529 & 0.963 & 0.697 \\
\hline \multicolumn{5}{|c|}{ Panel C: Services. } \\
\hline & Model 1 & Model 2 & Model 3 & Model 4 \\
\hline \multirow[t]{2}{*}{ Intercept } & $-6.166 * * *$ & $-6.287 * * *$ & $-26.331 * * *$ & $-7.315 * * *$ \\
\hline & -11.448 & -11.958 & -26.000 & -5.883 \\
\hline \multirow[t]{2}{*}{ Trend } & & $0.072 * * *$ & & $0.069 * * *$ \\
\hline & & 6.353 & & 17.078 \\
\hline \multirow[t]{2}{*}{ LogGdp } & $1.040 * * *$ & $1.010 * * *$ & $2.605 * * *$ & $1.092 * * *$ \\
\hline & 24.997 & 24.728 & 33.150 & 11.248 \\
\hline Pooled Effect & Yes & Yes & & \\
\hline Fixed Effect & & & Yes & \\
\hline Random Effect & & & & Yes \\
\hline No. of Obs. & 780 & 780 & 780 & 780 \\
\hline $\mathrm{R}^{2}$ & 0.445 & 0.421 & 0.965 & 0.681 \\
\hline
\end{tabular}
$* * *, * *$, and $*$ stand for statistical significance based on two-sided tests at the $1 \%, 5 \%$, and $10 \%$ level, respectively.

Panel A: Hardware. 
Although economic growth spurs investments in hardware (Panel A), software (Panel B) and services (Panel C) alike, the coefficient estimates are not the same as hypothesis $\mathrm{H} 4 \mathrm{a}$ claims. Although not all coefficient estimates of the hardware models (Panel A) are statistically significant (the time effect, Trend, terms), since their economic magnitudes are larger than those of the software models (Panel B), respectively, these results are in favor of hypothesis $H 4 b$. Panel $\mathrm{C}$ witnesses that investments in IT services rise over time (Trend) and income (LogGdp).

\subsection{Comparison with Existing Studies}

As we compare our results listed in Tables 5, 6 and 7, positive productivity effects of IT investments remain robust beyond 1990s into the first decade of the $21^{\text {st }}$ century.

Table 9

Comparable articles in the literature.

\begin{tabular}{lllrl}
\hline Reference & Sample Period & Factor & Coefficient & Income (Y) \\
\hline Brynjolfsson (1993) & $1987-1991$ & IT capital flow & 0.017 & Gross revenue \\
Brynjolfsson and Hitt (2003) & $1988-1992$ & IT capital stock & 0.088 & Value added \\
Lichenberg (1995) & $1988-1992$ & IT capital flow & 0.106 & Gross revenue \\
Lee and Baura (1997) & $1978-1984$ & IT capital flow & 0.040 & Gross revenue \\
Choe and Choi (2015) & $1995-2009$ & IT capital stock & 0.056 & Gross domestic products \\
\hline
\end{tabular}

\section{CONCLUSION}

Earlier studies have shown positive and large impacts of information technology (IT) investments on aggregate products in the nascent stage. However, this causal inference may not be applicable in the adult regime with a diminishing marginal productivity. We conduct a fifty cross-country analysis on a fifteen year (1995-2009) data of IT capital stocks and real variables rather than flows and nominal, respectively, as used in the literature. Controlling for country and time effects, the empirical implications of our study are as follows: First, the IT investment intensity positively affects aggregate productivity controlling for labor, assets, and financial markets. Second, the relative contribution has decreased as the law of diminishing returns predicts. Lastly, software and services have gained more capital allocation on relative terms in exchange for less on hardware. This finding contrasts with the existing argument that the hardware-software mix is time-constant due to substitution.

In order to leverage our results shown herein up to a feasible set of policy implications, we plan to buttress our research agenda with demystifying the propagation processes and time lags of the productivity effects of IT investments. Addressing these issues, prerequisites may be to augment control variables to minimize autoregressions and endogeneities of IT investments vis-à-vis aggregate products. Also, the binary dummy variable defined as ITdeveloped versus developing economy can be rendered as a country-specific categorical variable to control for a variety of sovereign-level conditions of IT development.

\section{ACKNOWLEDGEMENTS}

Special thanks are due to Seong Kook Kim, Songchun Moon, and Hee-Dong Yang. Standard disclaimer rules apply and all errors are of our own. This work was supported by the Ministry of Education of the Republic of Korea and the National Research Foundation of Korea (NRF-2015S1A5A2A01010876).

\section{AUTHOR'S NOTE}

Standard disclaimer rules apply and all errors are of our own. 


\section{AUTHOR BIOGRAPHIES}

Paul Moon Sub Choi is an assistant professor of finance at the College of Business Administration, Ewha Womans University. Before he joined Ewha in 2010, he had taught at the State University of New York at Binghamton. He received his degrees from Yonsei (B.A.), Harvard (A.M.), and Cornell University (Ph.D). (first author)

Hakyoul Choe is a Ph.D. candidate in managerial information systems at the KAIST Business School. He received his degrees from Yonsei (B.A.) and the KAIST (M.S.). (corresponding author)

\section{REFERENCES}

Anderson, M. C., Banker, R. D., Ravindran, S., 2003. The New Productivity Paradox. Communications of the ACM 46(3), 9194.

Autor, D. H., Levy, F., Murnane, R. J., 2003. The Skill Content of Recent Technological Change: An Empirical Exploration. Quarterly Journal of Economics 118(4), 1279-1334.

Baltagi, B. H., 2008. Econometric Analysis of Panel Data, 4th edition, Wiley.

Brynjolfsson, E., 1993. The Productivity Paradox of Information Technology. Communications of the ACM, 36(12), 66-77.

Brynjolfsson, E., Hitt, L. M., 2003. Computing Productivity: Firm-Level Evidence. The Review of Economics and Statistics 85(4), 793-808.

Chow, G. C., 1960. Tests of Equality between Sets of Coefficients in Two Linear Regressions. Econometrica 28(3), 591-605.

Choi, Y., 2009. Analyzing Economic Impact of Paperless Trade on International Trade. Trade Focus 9(64) of Institute for International Trade. (in Korean).

Cobb, C. W., Douglas, P. H., 1928. A Theory of Production. American Economic Review 18 (Supplement), 139-165.

Durbin, J., Watson, G. S., 1950. Testing for Serial Correlation in Least Squares Regression: I. Biometrika 37, 409-428.

Durbin, J., Watson, G. S., 1951. Testing for Serial Correlation in Least Squares Regression, II. Biometrika 38, $159-179$.

Gurbaxani, V., Mendelson, H., 1992. An Empirical Analysis of Software and Hardware Spending. Decision Support Systems $8(1), 1-16$.

Hitt, L. M., Wu, D. J., Zhou, X., 2002. ERP Investments: Business Impact and Productivity Measures. Journal of Management Information Systems 19(1), 71-98.

Kudyba, S., Diwan, R., 2002. Research Report: Increasing Returns to Information Technology. Information Systems Research 13(1), 104-111.

Larus, J., 2009. Spending Moore's Dividend. Communications of the ACM 52(5), 62-69.

Lee, B., Barua, A., 1999. An Integrated Assessment of Productivity and Efficiency Impacts of Information Technology Investments: Old Data, New Analysis and Evidence. Journal of Productivity Analysis 12(1), 21-43.

Loveman, G. W., 1988. An Assessment of the Productivity Impact on Information Technologies. MIT Management in the 1990s Working Paper \#88-054.

Mendelson, H., 1987. Economies of Scale in Computing: Grosch's Law Revisited. Communications of the ACM 30(12), 10661072 .

Mittal, N., Nault, B. R., 2009. Investments in Information Technology: Indirect Effects and Information Technology Intensity. Information Systems Research 20(1), 140-154.

OECD, 2008. Broadband Growth and Policies in OECD Countries. (downloaded on 2 May 2012 from http://www.oecd.org/dataoecd/32/57/40629067.pdf).

Park, J., Shin, S., Sanders, G. L., 2007. Impact of International Information Technology Transfer on National Productivity, Information Systems Research, 18(1), 86-102.

Slye, J., Peterson, D., Petty, A., 2010. Federal Information Technology Market 2010-2015. INPUT's Annual Forecast (downloaded on 12 November 2011 from http://iq.govwin.com/corp/library/detail.cfm?ItemID=12801\&bt2\&cmp=EMC-2feditfc070110).

World Bank, 2009. World Bank Development Indicators 2009. (downloaded on 2 February 2015 from http://data. World Bank.org/products/data-books/WDI-2009). 